\title{
O DIREITO À EDUCAÇÃO DE QUALIDADE E SUAS DECORRÊNCIAS PARA A GESTÃO ESCOLAR
}

\author{
EL DERECHO A UNA EDUCACIÓN DE CALIDAD Y SUS \\ DECORRENCIAS PARA LA GESTIÓN DE LA ESCUELA \\ THE RIGHT TO QUALITY EDUCATION \\ AND THEIR DECORENCES FOR SCHOOL MANAGEMENT
}

\author{
Jardelino MENEGAT ${ }^{1}$ \\ Dirleia Fanfa SARMENTO ${ }^{2}$ \\ Mary RANGEL ${ }^{3}$
}

RESUMO: Este artigo é decorrente de uma pesquisa de cunho documental que focaliza o direito à educação de qualidade e seus modos de efetivação em diferentes contextos. Neste texto, faz-se necessário um recorte dos indicativos da educação de qualidade presentes nos documentos difundidos pela UNESCO (Declaração Mundial sobre Educação para Todos - EPT: satisfazendo as necessidades básicas de aprendizagem; o Marco de Ação de Dakar - Educação para todos: assumindo nossos compromissos coletivos; e a Declaração e o Marco de Ação de Incheon: Rumo a uma educação de qualidade inclusiva e equitativa e à educação ao longo da vida de todos) e naqueles específicos do cenário brasileiro (Plano Nacional de Educação em Direitos Humanos, Diretrizes Nacionais para a Educação em Direitos Humanos, Diretrizes Curriculares Nacionais da Educação Básica e o Plano Nacional de Educação 2014-2024), analisando as decorrências desses indicativos para a gestão escolar. Os documentos foram analisados por meio da Técnica de Análise de Conteúdo. Dentre os desafios que se colocam à gestão escolar para a oferta de educação de qualidade, destacam-se: a gestão democrática; o desenvolvimento da cultura dos direitos humanos; a estruturação de ambientes de aprendizagem seguros e saudáveis; a existência de um projeto políticopedagógico alicerçado em valores humanistas; a articulação entre o educar e o cuidar; uma prática pedagógica pautada pelos princípios da liberdade, da igualdade, da equidade e da diversidade; o desenvolvimento de competências; a promoção da aprendizagem; a avaliação da qualidade educacional; a formação, a qualificação profissional e a valorização dos profissionais da educação.

PALAVRAS-CHAVE: Direito à educação. Educação de qualidade. Gestão escolar.

${ }^{1}$ Centro Universitário La Salle do Rio de Janeiro (Unilasalle-RJ), Niterói - RJ - Brasil. Universidade Católica de Brasília (Ucb), Brasília - DF - Brasil. Reitor e Professor do curso de Direito do Unilasalle-RJ e Chanceler da UCB. E-mail: jardelino.menegat@lasalle.org.br.

${ }^{2}$ Universidade La Salle (Unilasalle-RS), Canoas - RS - Brasil. Professora do curso de Pedagogia e do Programa de Pós-graduação em Educação da Universidade La Salle. E-mail: dirleia.sarmento@unilasalle.edu.br.

${ }^{3}$ Universidade Federal Fluminense (Uff), Niterói - RJ - Brasil. Universidade do Estado do Rio de Janeiro (Uerj), Rio de Janeiro - RJ - Brasil. Centro Universitário La Salle do Rio de Janeiro (Unilasalle-RJ), Niterói - RJ - Brasil. Professora Titular do Programa de Pós-graduação em Educação da UFF e Professora Titular do Programa de Pós-Graduação em Ciências Médicas da UERJ. Decana do UnilasalleRJ. E-mail: mary.rangel@lasalle.org.br.

RPGE - Revista on line de Política e Gestão Educacional, Araraquara, v. 22, n. esp.1, p. 105-136, mar., 2018. 
RESUMEN: Este artículo es el resultado de una investigación documental de naturaleza teórica que se centra en el derecho a la educación de calidad y sus modalidades de acción eficaz en diferentes contextos. En este texto se hace un recorte del indicativo de la calidad de la educación en documentos distribuidos por la UNESCO (Declaración Mundial sobre Educación para Todos - EPT: satisfacción de las necesidades básicas de aprendizaje; el Marco de Acción de Dakar - Educación para Todos: asumir nuestros compromisos colectivos; y la Declaración y el Marco de Acción de Inchon: hacia una educación de calidad inclusiva y equitativa y a la educación permanente de todos), y en los documentos específicos del escenario brasileño (Plan Nacional de Educación en Derechos Humanos; Lineamientos Nacionales para la Educación en Derechos Humanos: Lineamientos Curriculares Nacionales de la Educación Básica y el Plan Nacional de Educación 2014-2024), analizando las consecuencias de estas indicaciones para la administración de la escuela. Se analizaron los documentos por medio de la Técnica de Análisis de Contenido. Entre los retos de la gestión escolar para la provisión de educación de calidad se apuntan: la gestión democrática; el desarrollo de la cultura de los derechos humanos; estructuración de ambientes de aprendizaje seguro y saludable; la existencia de un proyecto político pedagógico basado en los valores humanistas; la articulación del hecho de educar y cuidado; una práctica pedagógica guiada por los principios de libertad, igualdad, equidad y diversidad; el desarrollo de habilidades; la promoción del aprendizaje; la evaluación de calidad de la educación; formación, calificación profesional y valorización de los profesionales de la educación.

PALABRAS CLAVES: Derecho a la educación. Educación de calidad. Gestión de la escuela.

ABSTRACT: The article is the result of a theoretical research, of documentary nature, which focuses on the right to quality education and its modes of implementation in different contexts. In this text, a contour is made in the indicatives of quality education in the documents disseminated by UNESCO (World Declaration on Education for All: meeting basic learning needs; the Dakar Framework for Action - Education for All: Taking on board our commitments Incheon Declaration and Framework for Action: Towards Inclusive and Equitable Quality Education and Lifelong Education for All) and those specific to the Brazilian scenario (National Human Rights Education Plan, National Guideline Education in Human Rights, National Curricular Guidelines for Basic Education and the National Education Plan 2014-2024), analyzing the consequences of these indicatives for school management, the documents were analyzed through the Content Analysis Technique. Among the challenges facing school management for the provision of quality education, the following stand out: Democratic management, the development of a human rights culture; the structuring of safe and healthy learning environments; the existence of a political-pedagogical project based on humanistic values; the articulation between educating and caring; a pedagogical practice based on the principles of freedom, equality, equity and diversity; the development of skills; the promotion of learning; the evaluation of educational quality; academic formation, professional qualification and enhancement of education professionals.

KEYWORDS: Right to education. Quality education. School management.

RPGE - Revista on line de Política e Gestão Educacional, Araraquara, v. 22, n. esp.1, p. 105-136, mar., 2018. 


\section{Introdução}

$\mathrm{O}$ direito à educação ganhou acento no âmbito mundial com a Declaração Universal dos Direitos Humanos (ONU, 1948), sendo considerado ao lado de um conjunto de outros direitos fundamentais à dignidade humana a serem assegurados a todas as pessoas. Pautada numa visão de Direitos Humanos e alicerçada na universalidade, na indivisibilidade e na interdependência, ressalta a importância da educação para a efetivação dos demais direitos. Em seu artigo 26, que trata da educação, a Declaração estabelece o direito à educação, à gratuidade e à obrigatoriedade "pelo menos nos graus elementares e fundamentais". A educação será "orientada no sentido do pleno desenvolvimento da personalidade humana e do fortalecimento do respeito pelos direitos humanos e pelas liberdades fundamentais", promovendo "a compreensão, a tolerância e a amizade entre todas as nações e grupos raciais ou religiosos, e coadjuvará as atividades das Nações Unidas em prol da manutenção da paz". (ONU, 1948, Art. 26). Passados quase cinquenta anos da Declaração Universal, no início da década de noventa a Declaração Mundial sobre Educação para Todos (UNESCO, 1990), conhecida como EPT, impulsiona uma mobilização internacional sobre o direito à educação, estabelecendo metas a serem cumpridas pelos países signatários, com ênfase na qualidade educacional. Tal Declaração, articulada a outros movimentos, mobilizou vários países a realizarem mudanças significativas em termos de dispositivos legais, políticas públicas educacionais, programas e ações com vistas a assegurar o acesso, a permanência e o sucesso dos estudantes na Educação Básica.

No final dos anos 90, o "Relatório para a UNESCO da Comissão Internacional sobre Educação para o século XXI", Comissão esta presidida por Jacques Delors, inicia o primeiro capítulo fazendo a seguinte alusão: "Perante os múltiplos desafios suscitados pelo futuro, a educação surge como um trunfo indispensável para que a humanidade tenha a possibilidade de progredir na consolidação dos ideais da paz, da liberdade e da justiça social”. (2010, p. 5). Ainda:

[...] a Comissão faz questão de afirmar sua fé no papel essencial da educação para o desenvolvimento contínuo das pessoas e das sociedades: não como um remédio milagroso, menos ainda como um "abre-te sésamo" de um mundo que tivesse realizado todos os seus ideais, mas como uma via - certamente, entre outros caminhos, embora mais eficaz - a serviço de um desenvolvimento humano mais harmonioso e autêntico, de modo a contribuir para a diminuição da pobreza, da exclusão social, das incompreensões, das opressões, das guerras. (Ibidem, grifo do autor).

RPGE - Revista on line de Política e Gestão Educacional, Araraquara, v. 22, n. esp.1, p. 105-136, mar., 2018. 
No contexto brasileiro, a Constituição da República Federativa do Brasil (Brasil, 1988), alicerçada no princípio do Estado Democrático de Direito, enfatiza a dignidade humana como princípio fundamental. Tal ênfase propiciou a ratificação de vários acordos internacionais em prol dos direitos humanos em nosso país. Dentre esses, destacamos a Convenção Internacional dos Direitos da Criança (1989), ratificada no Brasil em 1990. Sob a premissa que a criança é um sujeito de direitos humanos, o documento estabelece em seus cinquenta e quatro artigos um conjunto de direitos fundamentais que devem ser assegurados a todas as crianças, definindo o princípio normativo do "interesse maior da criança" (Art. 3), delegando à família, à sociedade e ao Estado o dever de protegê-la e assegurar que seus direitos sejam observados (BRASIL, 1990a).

A partir da década de oitenta e, de forma mais contundente, na década de 90 , várias transformações foram sendo postas em curso em termos de organização e de estrutura do sistema educacional brasileiro (VIEIRA, 2006; MEDEIROS; LUCE, 2006), sendo várias delas impulsionadas pelos dispositivos legais difundidos no âmbito internacional, os quais têm repercutido ainda hoje na gestão democrática e na democratização da educação brasileira. Destacamos, neste contexto, iniciativas tais como: a aprovação do Estatuto da Criança e do Adolescente (BRASIL, 1990b); a Lei de Diretrizes e Bases da Educação Nacional (BRASIL, 1996); os Parâmetros Curriculares Nacionais (BRASIL, 1997); a instituição do Sistema de Avaliação da Educação Básica (2005); a ampliação do Ensino Fundamental para nove anos (BRASIL, 2006); o Plano de Desenvolvimento da Educação (Brasil, 2007a); o Plano de Metas Compromisso Todos pela Educação (BRASIL, 2007b); o Plano Nacional de Educação em Direitos Humanos (BRASIL, 2007c); o Programa Mais Educação (BRASIL, 2010); as Diretrizes Nacionais para a Educação em Direitos Humanos (BRASIL, 2012a); a instituição do Pacto Nacional pela Alfabetização na Idade Certa (BRASIL, 2012b); a revitalização das Diretrizes Curriculares Nacionais da Educação Básica (BRASIL, 2013), o Plano Nacional da Educação 2014-2024 (BRASIL, 2014), dentre outros.

Sem dúvida, todo esse movimento no cenário brasileiro em prol do direito à educação de qualidade (dentro do escopo dos demais direitos) em termos de dispositivos legais, políticas públicas educacionais, programas e ações, traz decorrências diretas para a gestão escolar, pois é no cotidiano educacional que a ação educativa se materializa. Dessa forma, neste texto, com base numa pesquisa que vimos realizando sobre o direito à educação de qualidade e seus modos de efetivação em diferentes 
contextos, fazemos um recorte analítico problematizando a seguinte questão: Quais são as decorrências dos indicativos de educação de qualidade para a gestão escolar, presentes em dispositivos legais que versam sobre o direito à educação, difundidos pela UNESCO e nos dispositivos nacionais que orientam a ação educativa no cenário brasileiro?

Ao falarmos em educação de qualidade, logo vem à tona o questionamento sobre o que significa tal qualidade. Apesar de ser um conceito presente nos dispositivos legais, é possível constatar que as definições são, ainda, um tanto difusas, dado o caráter polissêmico desse conceito. Não temos a intenção de aprofundar e/ou discutir os múltiplos significados, as possibilidades e as limitações conceituais neste texto, dependendo do contexto em que tal termo é empregado. De acordo com o PDE (BRASIL, 2007, p. 41):

Qualidade entendida como enriquecimento do processo educacional, participação dos sujeitos e valorização das diferenças, de modo que as oportunidades educacionais se constituam em formas reais de reconhecimento e desenvolvimento das potencialidades, conhecimentos e competências. A melhoria da qualidade da educação e a redução de desigualdades relativas às oportunidades educacionais - em outras palavras, o direito de aprender - são suas razões constitutivas.

Ao abordar o conceito de qualidade, o Parecer CNE/CEB n ${ }^{\circ}$ 7/2010 assevera que tal conceito estabelece relações com "uma determinada ideia de qualidade de vida na sociedade e no planeta Terra", pois "Inclui tanto a qualidade pedagógica quanto a qualidade política, uma vez que requer compromisso com a permanência do estudante na escola, com sucesso e valorização dos profissionais da educação". Desse ponto de vista:

Trata-se da exigência de se conceber a qualidade na escola como qualidade social, que se conquista por meio de acordo coletivo. Ambas as qualidades - pedagógica e política - abrangem diversos modos avaliativos comprometidos com a aprendizagem do estudante, interpretados como indicações que se interpenetram ao longo do processo didático-pedagógico, o qual tem como alvo $\mathrm{o}$ desenvolvimento do conhecimento e dos saberes construídos histórica e socialmente.

Inspiramo-nos, na compreensão de Libâneo, Oliveira e Toschi (2003, p. 117-118), quando fazem alusão à educação de qualidade como 
[...] aquela mediante a qual a escola promove, para todos, o domínio dos conhecimentos e o desenvolvimento de capacidades cognitivas e afetivas indispensáveis ao atendimento de necessidades individuais e sociais dos alunos, bem como a inserção no mundo e a constituição da cidadania também como poder de participação, tendo em vista a construção de uma sociedade mais justa e igualitária. Qualidade é, pois, conceito implícito à educação e ao ensino.

O artigo está estruturado da seguinte forma: inicialmente, introduzimos a temática analítica; a seguir, na seção denominada Abordagem Metodológica, descrevemos os procedimentos metodológicos do estudo; posteriormente, na seção Gestão Escolar: por uma educação de qualidade, dedicamo-nos à análise e interpretação dos indicativos de educação de qualidade, identificados nos documentos constituintes do corpus investigativo, destacando suas decorrências para a gestão escolar; e, por fim, apresentamos, em termos de síntese, algumas considerações finais sobre as reflexões apresentadas ao longo do texto.

\section{Abordagem metodológica}

O artigo decorrente de uma pesquisa teórica, de cunho documental, que focaliza o direito à educação de qualidade e seus modos de efetivação em diferentes contextos. Analisamos as decorrências dos indicativos de educação de qualidade para a gestão escolar, presentes em dispositivos legais. No entender de Appolinário (2009, p. 67), o documento é "Qualquer suporte que contenha informação registrada, formando uma unidade, que possa servir para consulta, estudo ou prova”. Pádua considera como documento "toda base de conhecimento fixado materialmente e suscetível de ser utilizado para consulta, estudo ou prova" (PÁDUA, 2011, p. 69, grifo da autora). Conforme Godoy (1995, p. 23), “A escolha dos documentos não é um processo aleatório, mas se dá em função de alguns propósitos, ideias ou hipóteses”. Nessa linha reflexiva, partilhamos a compreensão de Flick (2009, p. 232), quando refere que "Ao decidir-se pela utilização de documentos em um estudo, deve-se sempre vê-los como meios de comunicação”. O autor continua explicando que

O pesquisador deverá também perguntar-se acerca de: quem produziu esse documento, com que objetivo e para quem? Quais eram as intenções pessoais ou institucionais com a produção e o provimento desse documento ou dessa espécie de documento? Os documentos não são, portanto, apenas simples dados que se pode usar como recurso para a pesquisa. Uma vez que comece a utilizá-los para a pesquisa, ao

RPGE - Revista on line de Política e Gestão Educacional, Araraquara, v. 22, n. esp.1, p. 105-136, mar., 2018. 
mesmo tempo o pesquisador deve sempre focalizar esses documentos enquanto um tópico de pesquisa: quais são suas características, em que condições específicas foram produzidos, e assim por diante. (FLICK, 2009, p. 232-233).

Tendo presente tais considerações, compõem o corpus investigativo do estudo os seguintes documentos difundidos no âmbito mundial: a Declaração Mundial sobre Educação para Todos: satisfazendo as necessidades básicas de aprendizagem (UNESCO, 1990); o Marco de Ação de Dakar - Educação para todos: assumindo nossos compromissos coletivos (UNESCO; CONSED; AÇÃO EDUCATIVA, 2001); e a Declaração e o Marco de Ação de Incheon: Rumo a uma educação de qualidade inclusiva e equitativa e à educação ao longo da vida de todos (UNESCO, 2015). A Conferência Mundial sobre Educação para Todos, realizada de 5 a 9 de março de 1990, e organizada pela UNESCO, ocorreu em Jomtien, na Tailândia. Durante a Conferência foi estipulada a Declaração Mundial de Educação para Todos: Satisfação das Necessidades Básicas de Aprendizagem (1990), com o intuito de impulsionar os esforços para oferecer educação adequada para toda a população em seus diferentes níveis de ensino.

O Marco de Ação de Dakar - Educação para Todos é um documento decorrente das reflexões oriundas do Fórum Mundial de Educação 2000, realizado em abril de 2000, na capital do Senegal, Dakar. Nesse Fórum foram retomados os objetivos e as metas assumidos na Declaração Mundial de Educação para Todos (1990), tendo presente a consideração do reduzido avanço obtido em relação ao proposto. Reafirma-se a ideia de que

A visão de Jomtien continua pertinente e poderosa. Fornece uma perspectiva ampla e abrangente da educação e de seu papel crítico na outorga de poder aos indivíduos e na transformação das sociedades. Entre seus princípios essenciais encontram-se o acesso universal à aprendizagem; a atenção especial sobre equidade; a ênfase sobre os resultados da aprendizagem; a ampliação dos recursos e da esfera de ação da educação fundamental; a maior importância ao ambiente para o ensino; e o fortalecimento das parcerias. Lamentavelmente, a realidade tem focado aquém dessa visão: a milhões de pessoas ainda é negado o direito à educação e às oportunidades que ela dá para que se viva uma vida mais segura, mais saudável, mais produtiva e mais satisfatória. Essa eficiência tem múltiplas causas: débil vontade política, recursos financeiros insuficientes e utilização ineficiente dos disponíveis, encargos da dúvida, atenção inadequada às necessidades de ensino dos pobres e excluídos, falta de atenção à qualidade do ensino e ausência do compromisso de superar as disparidades de gênero. Não resta dúvida de

RPGE - Revista on line de Política e Gestão Educacional, Araraquara, v. 22, n. esp.1, p. 105-136, mar., 2018. 
que são tremendos os obstáculos para alcançar a educação para todos. Contudo, eles podem e devem ser superados. (UNESCO; CONSED; 2001, p. 15).

O documento faz um chamamento para que todos assumam, coletivamente, o compromisso assumido, salientando que "Os governos têm a obrigação de assegurar que os objetivos e as metas de EPT sejam alcançados e mantidos [...] por meio de amplas parcerias no âmbito de cada país, apoiadas pela cooperação com agências e instituições regionais e internacionais" (UNESCO; CONSED; AÇÃO EDUCATIVA, 2001, p. 8). A Declaração de Incheon é decorrente do Fórum Mundial de Educação de 2015, realizado na cidade de Incheon, na Coreia do Sul. No preâmbulo do documento é salientado que

Nesta ocasião histórica, reafirmamos a visão do movimento global Educação para Todos, iniciado em Jomtien, em 1990, e reiterado em Dakar, em 2000 - o mais importante compromisso com a educação nas últimas décadas, que tem ajudado a promover progressos significativos na educação. Reafirmamos também que a visão e a vontade políticas serão refletidas em inúmeros tratados de direitos humanos, internacionais e regionais, que estabelecem o direito à educação e sua inter-relação com outros direitos humanos. Reconhecemos os esforços feitos; contudo, constatamos, com grande preocupação, que estamos longe de alcançar a educação para todos. Recordamos o Acordo de Mascate, desenvolvido por meio de amplas consultas e aprovado na Reunião Mundial sobre Educação para Todos (EPT) em 2014, e que ajudou a guiar com sucesso os objetivos de educação propostos pelo Grupo de Trabalho Aberto dos Objetivos de Desenvolvimento Sustentável (ODS). Recordamos, ainda, os resultados das conferências ministeriais regionais sobre educação pós2015 e tomamos nota das conclusões do Relatório de Monitoramento Global de EPT 2015 e dos relatórios regionais de EPT. Reconhecemos a importante contribuição da Iniciativa Global Educação em Primeiro Lugar, assim como o papel dos governos e das organizações regionais, intergovernamentais e não governamentais no estímulo ao compromisso político em favor da educação.

A Declaração de Incheon contempla cinco temas, com ações a serem desenvolvidas entre 2015 e 2030, a partir dos compromissos do movimento Educação para Todos (EPT), sendo a educação de qualidade um desses temas. De acordo com o documento, o Marco de Ação da Educação 2030

[...] oferece orientações para a implementação da Educação 2030, foi discutido no FME 2015 e seus elementos básicos foram acordados na Declaração de Incheon. Ele foi finalizado pelo Grupo Redator para o Marco de Ação da Educação 2030 e adotado por 184 Estados-

RPGE - Revista on line de Política e Gestão Educacional, Araraquara, v. 22, n. esp.1, p. 105-136, mar., 2018. 
membros e pela comunidade educacional durante um encontro de altonível na UNESCO, em Paris, em 4 de novembro de 2015. O Marco de Ação aponta para como traduzir na prática e nos âmbitos nacional, regional e global o compromisso firmado em Incheon. Ele visa mobilizar todos os países e parceiros em torno do ODS sobre educação e suas metas, além de propor formas de implementar, coordenar, financiar e monitorar a Educação 2030 para garantir oportunidades de educação de qualidade inclusiva e equitativa, assim como de aprendizagem ao longo da vida para todos. Ele também propõe estratégias indicativas, nas quais os países possam se basear para desenvolver planos e estratégias contextualizados, que levem em consideração realidades nacionais, capacidades e níveis de desenvolvimento diferentes, e respeitem políticas e prioridades nacionais.

O documento está estruturado em três seções, a saber: visão, fundamentos e princípios; objetivo, abordagens estratégicas, metas e indicadores; e modalidades de implementação.

Do cenário brasileiro elegemos como referências o Plano de Educação em Direitos Humanos (BRASIL, 2007), as Diretrizes Nacionais para a Educação em Direitos Humanos (BRASIL, 2012), o Parecer CNE/CEB N $7 / 2010$, que trata sobre as Diretrizes Curriculares Nacionais da Educação Básica (Brasil, 2013) e o Plano Nacional de Educação 2014-2024 (BRASIL, 2014). O Plano Nacional de Educação em Direitos Humanos (PNEDH) foi aprovado em 2007. O documento reafirma a ideia da educação "como um direito em si mesmo e um meio indispensável para o acesso a outros direitos" (BRASIL, 2007, p. 25). De acordo com o documento,

A implementação do Plano Nacional de Educação em Direitos Humanos visa, sobretudo, difundir a cultura de direitos humanos no país. Essa ação prevê a disseminação de valores solidários, cooperativos e de justiça social, uma vez que o processo de democratização requer o fortalecimento da sociedade civil, a fim de que seja capaz de identificar anseios e demandas, transformando-as em conquistas que só serão efetivadas, de fato, na medida em que forem incorporadas pelo Estado brasileiro como políticas públicas universais. (BRASIL, 2007, p. 26).

A estrutura do Plano contempla, além da introdução: objetivos gerais; linhas gerais de ação; concepções e princípios; ações programáticas para a Educação Básica, a Educação Superior, a Educação não formal, a Educação dos profissionais dos Sistemas de Justiça e Segurança, e a Educação e Mídia. (BRASIL, 2007). Em decorrência da primeira ação programática prevista pelo PNEDH, que estabelece "a inserção da educação em direitos humanos nas diretrizes curriculares” (Brasil, 2007, p. 33), em 
2012, por meio da Resolução $\mathrm{N}^{\mathrm{o}} 1$ do Conselho Nacional de Educação, foram instituídas as Diretrizes Nacionais para a Educação em Direitos Humanos, a "serem observadas pelos sistemas de ensino e suas instituições” (BRASIL, 2012). No Art. $2^{\text {o da }}$ Resolução é enfatizado que:

A Educação em Direitos Humanos, um dos eixos fundamentais do direito à educação, refere-se ao uso de concepções e práticas educativas fundadas nos direitos humanos e em seus processos de promoção, proteção, defesa e aplicação na vida cotidiana e cidadã de sujeitos de direitos e de responsabilidades individuais e coletivas.

O Parecer CNE/CEB n ${ }^{\circ} 7 / 2010$, que trata das Diretrizes Curriculares Nacionais para a Educação Básica (BRASIL, 2013), contempla as diretrizes relativas à base nacional comum e demais orientações a serem observadas por todas as redes de ensino. Na apresentação do documento, Aloízio Mercadante, na época Ministro da Educação, explica que

\begin{abstract}
A necessidade da atualização das Diretrizes Curriculares Nacionais surgiu da constatação de que as várias modificações - como o Ensino Fundamental de nove anos e a obrigatoriedade do ensino gratuito dos quatro aos 17 anos de idade - deixaram as anteriores defasadas. Essas mudanças ampliaram consideravelmente os direitos à educação das nossas crianças e adolescentes e também de todos aqueles que não tiveram oportunidade de estudar quando estavam nessa fase da vida. Diante dessa nova realidade e em busca de subsídios para a formulação de Novas Diretrizes Curriculares Nacionais, a Câmara da Educação Básica do Conselho Nacional de Educação promoveu uma série de estudos, debates e audiências públicas, com a anuência e participação das entidades representativas dos dirigentes estaduais e municipais, professores e demais profissionais da educação, instituições de formação de professores, mantenedoras do ensino privado e de pesquisadores da área. (BRASIL, 2013, apresentação).
\end{abstract}

O Plano Nacional de Educação (PNE) foi oficializado pela Lei Federal $n^{\circ}$ 13.005, de 25 de junho de 2014 (BRASIL, 2014), com vigência até o ano de 2024. Pautado no que preconizam outros dispositivos legais que o antecedem, o PNE apresenta um conjunto de diretrizes a serem observadas e cumpridas pelos sistemas de ensino no Brasil. O PNE também define 20 metas a serem cumpridas por todo e qualquer dirigente de Estado, no espaço máximo de dez anos.

Elegemos esse conjunto de documentos, considerando a sua representatividade em termos constitutivos, o espaço temporal em que foram produzidos e difundidos, a abrangência, a relevância para as políticas públicas, programas e ações educacionais que

RPGE - Revista on line de Política e Gestão Educacional, Araraquara, v. 22, n. esp.1, p. 105-136, mar., 2018. 
incidem diretamente nos processos e práticas da gestão escolar, com vistas à sua materialização nas práticas educativas cotidianas.

Os documentos foram analisados por meio da Técnica de Análise de Conteúdo, proposta por Bardin (2011), sendo os indicativos de educação de qualidade identificados organizados em dez eixos temáticos: a) Gestão democrática; b) Desenvolvimento da cultura dos Direitos Humanos; c) Estruturação de ambientes de aprendizagem seguros e saudáveis; d) Existência de um projeto político-pedagógico alicerçado em valores humanistas; e) Articulação entre o educar e o cuidar; f) Prática pedagógica pautada pelos princípios da liberdade, da igualdade, da equidade e da diversidade; g) Desenvolvimento de competências; h) Promoção da aprendizagem; i) Avaliação da qualidade educacional; e j) Formação, a qualificação profissional e a valorização dos profissionais da educação. Esses indicativos são discutidos na próxima seção.

\section{Gestão escolar: por uma educação de qualidade}

A abordagem reflexiva acerca da gestão escolar pressupõe termos presente que a gestão escolar implica “[...] gerir a dinâmica cultural da escola, afinada com as diretrizes e políticas educacionais públicas para a implementação de seu projeto político-pedagógico" (LÜCK, 2009, p. 25). No entender de Libâneo, Oliveira e Toschi (2003, p. 293),

[...] a organização e a gestão referem-se ao conjunto de normas, diretrizes, estrutura organizacional, ações e procedimentos que asseguram a racionalização do uso de recursos humanos, materiais, financeiros e intelectuais, assim como a coordenação e o acompanhamento do trabalho das pessoas. Por racionalização do uso de recursos compreende-se a escolha racional de meios compatíveis com os fins visados e a adequada utilização desses recursos, que assegure a melhor realização desses fins. Por coordenação $e$ acompanhamento compreendem-se as ações e os procedimentos destinados a reunir, a articular e a integrar as atividades das pessoas que atuam na escola, para alcançar objetivos comuns. Para que essas duas características mais gerais de uma instituição se efetivem, são postas em ação as funções específicas de planejar, organizar, dirigir e avaliar. A condução dessas funções, mediante várias ações e procedimentos é o que se designa gestão, a atividade que põe em ação um sistema organizacional. (grifo dos autores). 
Dessa forma, a gestão escolar objetiva "promover a organização, a mobilização e a articulação de todas as condições materiais e humanas" visando "garantir o avanço dos processos socioeducacionais dos estabelecimentos de ensino, orientados para a promoção efetiva da aprendizagem dos alunos”. (LÜCK, 2009, p. 25). Nessa perspectiva:

Os gestores escolares, constituídos em uma equipe de gestão, são os profissionais responsáveis pela organização e orientação administrativa e pedagógica da escola, da qual resulta a formação da cultura e do ambiente escolar, que devem ser mobilizadores e estimuladores do desenvolvimento, da construção do conhecimento e da aprendizagem orientada para a cidadania competente. (LUCK, 2009, p. 22).

Feitas tais considerações, passamos à discussão dos indicativos da educação de qualidade, identificados no corpus investigativo, estabelecendo interlocução com autores que discutem a temática, presente em cada eixo em tela.

\section{a) Gestão democrática}

A gestão democrática está presente no ideário teórico e legal contemporâneo que trata dos processos e práticas gestoras das organizações, independentemente da tipologia que as caracteriza. A Constituição da República (Brasil, 1988) "consagrou a gestão democrática do ensino público como princípio, fato inédito em relação às Constituições anteriores” (MEDEIROS, LUCE, 2006, p.18). A LDB (Brasil, 1996) estabelece que o ensino será ministrado tendo como um de seus princípios a "gestão democrática do ensino público, na forma desta Lei e da legislação dos sistemas de ensino" (BRASIL, 1996, Art. $3^{\circ}$ ). O PNE (Brasil, 2014) reitera, numa de suas diretrizes, a "promoção do princípio da gestão democrática da educação pública" (Cf. Art. $2^{\circ}$ ). Na meta 19, estabelece: “Assegurar condições, no prazo de dois anos, para a efetivação da gestão democrática da educação, associada a critérios técnicos de mérito e desempenho e à consulta pública à comunidade escolar, no âmbito das escolas públicas [...]”. A partir deste conjunto de dispositivos é possível identificarmos as seguintes dimensões: a gestão democrática da educação e a democratização da educação. Conforme explicam Medeiros e Luce (2006, p. 18-19):

[...] a gestão democrática da educação está associada ao estabelecimento de mecanismos institucionais e à organização de ações que desencadeiem processos de participação social: na

RPGE - Revista on line de Política e Gestão Educacional, Araraquara, v. 22, n. esp.1, p. 105-136, mar., 2018. 
formulação de políticas educacionais; na determinação de objetivos e fins da educação; no planejamento; nas tomadas de decisão; na definição sobre alocação de recursos e necessidades de investimentos; na execução das deliberações; nos momentos de avaliação. Esses processos devem garantir e mobilizar a presença dos diferentes atores envolvidos nesse campo, no que se refere aos sistemas, de um modo geral, e nas unidades de ensino - as escolas e universidades. Já a democratização da educação está mais associada à democratização do acesso e a estratégias globais que garantam a continuidade dos estudos, tendo como horizonte a universalização do ensino para toda a população, bem como o debate sobre a qualidade social dessa educação universalizada. (grifo das autoras).

Importante retomar que a gestão democrática inclui "a participação ativa de todos os professores e da comunidade escolar como um todo, de modo a contribuírem para a efetivação da gestão democrática que garante qualidade para todos os alunos" (LÜCK, 2009, p. 23). Desse ponto de vista, é fundamental a atuação dos órgãos colegiados, que são organizadores da participação dos membros da comunidade escolar na gestão; a escolha dos diretores pela comunidade educativa; a promoção de espaços e tempos para a participação da família nas ações diversas e na tomada de decisões atinentes à escola. Esse processo de democratização da escola também contribui para “promover a educação para a mudança e a transformação social” e, dessa forma, um de seus princípios estruturantes e a democracia na educação (BRASIL, 2012, Art. $3^{\circ}$ ). Assim, a democratização da educação concebida a partir da participação coletiva pressupõe a abertura de espaços, tempos e instâncias que viabilizem e promovam a corresponsabilidade de todos os atores, sendo que escola democrática, no entender de Lück (2009, p. 69-70),

[...] é aquela em que os seus participantes estão coletivamente organizados e compromissados com a promoção de educação de qualidade para todos. A democracia constitui-se em característica fundamental de sociedades e grupos centrados na prática dos direitos humanos, por reconhecerem não apenas o direito de as pessoas usufruírem dos bens e dos serviços produzidos em seu contexto, mas também, e sobretudo, seu direito e seu dever de assumirem responsabilidade pela produção e melhoria desses bens e serviços. Com essa perspectiva, direitos e deveres são dois conceitos indissociáveis, de modo que, falando-se de um, remete-se ao outro necessariamente. E é nessa junção que se estabelece a verdadeira democracia, construída mediante participação qualificada pela cidadania e construção do bem comum.

Na consolidação da gestão democrática, a atuação de órgãos colegiados (por exemplo, o Conselho Escolar, as agremiações estudantis) que são organizadores da 
participação dos membros da comunidade escolar na gestão é essencial, pois a ação educativa "demanda não apenas um grande quadro funcional, como também a participação da comunidade, dos pais e de organizações diversas, para efetivá-lo com a qualidade necessária" (LÜCK, 2009, p. 19).

\section{b) Desenvolvimento da cultura dos Direitos Humanos}

A questão dos Direitos Humanos é tema central no Plano Nacional de Educação em Direitos Humanos (PNEDH) e nas Diretrizes Nacionais para a Educação em Direitos Humanos (DNEDH). Ambos enfatizam a Educação em Direitos Humanos como elemento fundamental para o desenvolvimento da cultura dos Direitos Humanos na escola. Desse ponto de vista,

[...] a educação é compreendida como um direito em si mesmo e um meio indispensável para o acesso a outros direitos. A educação ganha, portanto, mais importância quando direcionada ao pleno desenvolvimento humano e às suas potencialidades, valorizando o respeito aos grupos socialmente excluídos. Essa concepção de educação busca efetivar a cidadania plena para a construção de conhecimentos, o desenvolvimento de valores, atitudes e comportamentos, além da defesa socioambiental e da justiça social. (BRASIL, 2007, p. 25).

Diante disso, na contemporaneidade, a concepção de direitos humanos está alicerçada em conceitos, tais como "[...] cidadania democrática, cidadania ativa e cidadania planetária, por sua vez inspiradas em valores humanistas e embasadas nos princípios da liberdade, da igualdade, da equidade e da diversidade, afirmando sua universalidade, indivisibilidade e interdependência” (BRASIL, 2007, p. 23). Nesse sentido, a educação é elemento fundamental para a consolidação da cultura democrática, sendo uma de suas finalidades a "formação do sujeito de direitos" (BRASIL, 2007), preparando-o para o exercício da cidadania (BRASIL, 1988, 1996). Desse ponto de vista,

[...] a educação é compreendida como um direito em si mesmo e um meio indispensável para o acesso a outros direitos. A educação ganha, portanto, mais importância quando direcionada ao pleno desenvolvimento humano e às suas potencialidades, valorizando o respeito aos grupos socialmente excluídos. Essa concepção de educação busca efetivar a cidadania plena para a construção de conhecimentos, o desenvolvimento de valores, atitudes e 
comportamentos, além da defesa socioambiental e da justiça social. (BRASIL, 2007, p. 25).

As Diretrizes Nacionais para a Educação em Direitos Humanos, a "serem observadas pelos sistemas de ensino e suas instituições" (BRASIL, 2012, Art. $1^{\text {o }}$ ), apresentam, no Art. $2^{\circ}$ :

A Educação em Direitos Humanos, um dos eixos fundamentais do direito à educação, refere-se ao uso de concepções e práticas educativas fundadas nos direitos humanos e em seus processos de promoção, proteção, defesa e aplicação na vida cotidiana e cidadã de sujeitos de direitos e de responsabilidades individuais e coletivas.

Conforme o Parecer CNE/CEB No 7/2010, a educação é "um instrumento imprescindível para que o indivíduo reconheça a si próprio como agente ativo na modificação da mentalidade de seu grupo, sendo protagonista na construção de uma democracia" (BRASIL, 2010). Enquanto um direito, ela é fundamental para que os outros direitos humanos possam se efetivar, pois "são aqueles que o indivíduo possui simplesmente por ser uma pessoa humana, por sua importância de existir” [...]. São direitos fundamentais, reconhecidos no âmbito internacional, garantidos pelo sistema social do qual o indivíduo faz parte. (BRASIL, 2010). O PNEDH salienta a necessidade de a educação articular as seguintes dimensões:

a) apreensão de conhecimentos historicamente construídos sobre direitos humanos e a sua relação com os contextos internacional, nacional e local; b) afirmação de valores, atitudes e práticas sociais que expressem a cultura dos direitos humanos em todos os espaços da sociedade; c) formação de consciência cidadã capaz de se fazer presente em níveis cognitivo, social, ético e político; d) desenvolvimento de processos metodológicos participativos e de construção coletiva, utilizando linguagens e materiais didáticos contextualizados; e) fortalecimento de práticas individuais e sociais que gerem ações e instrumentos em favor da promoção, da proteção e da defesa dos direitos humanos, bem como da reparação das violações. (BRASIL, 2007, p. 25).

O Parecer CNE/CEB N $\mathrm{N}^{\circ} 7 / 2010$ apresenta como uma das missões da escola a "de construir a cultura de direitos humanos para preparar cidadãos plenos", pois

Compreender e realizar a Educação Básica, no seu compromisso social de habilitar o estudante para o exercício dos diversos direitos, significa, portanto, potencializá-lo para a prática cidadã com

RPGE - Revista on line de Política e Gestão Educacional, Araraquara, v. 22, n. esp.1, p. 105-136, mar., 2018. 
plenitude, cujas habilidades se desenvolvem na escola e se realizam na comunidade onde os sujeitos atuam.

Nesse contexto, compreendida como uma comunidade educativa, a escola deve primar pelo desenvolvimento da cultura dos direitos humanos, assegurando que "os objetivos e as práticas a serem adotados sejam coerentes com os valores e princípios da educação em direitos humanos" (BRASIL, 2007, p. 32). Isso significa que a equipe de gestão escolar tem como desafio assegurar que os processos, desde o planejamento até a avaliação da ação educativa, transcorram em "espaços marcados pelo entendimento mútuo, respeito e responsabilidade [...]", e que "a prática escolar deve ser orientada para a educação em direitos humanos, assegurando o seu caráter transversal e a relação dialógica entre os diversos atores sociais". (BRASIL, 2007, p. 32). Nessa relação dialógica,

[...] a educação em direitos humanos deve estruturar-se na diversidade cultural e ambiental, garantindo a cidadania, o acesso ao ensino, permanência e conclusão, a equidade (étnico-racial, religiosa, cultural, territorial, físico-individual, geracional, de gênero, de orientação sexual, de opção política, de nacionalidade, dentre outras) e a qualidade da educação.

Ora, sendo a escola uma organização que possui cultura própria, composta por um conjunto de concepções, valores e práticas educativas, a incorporação dos Direitos Humanos nessa cultura pressupõe uma série de ações que contribuam para a vivência de experiências e a materialização desses direitos já no cotidiano escolar. Os princípios da Educação em Direitos Humanos, por exemplo, são basilares para essa cultura, de forma que a escola seja um espaço educador que prime pela solidariedade, o respeito a diversidade, o repúdio a qualquer forma de discriminação e a violência, o exercício da cidadania, dentre outros.

\section{c) Estruturação de ambientes de aprendizagem seguros e saudáveis}

O ambiente adequado à aprendizagem é enfatizado no sexto artigo da Declaração Mundial sobre Educação para Todos (UNESCO, 1990):

A aprendizagem não ocorre em situação de isolamento. Portanto, as sociedades devem garantir a todos os educandos assistência em nutrição, cuidados médicos e o apoio físico e emocional essencial para

RPGE - Revista on line de Política e Gestão Educacional, Araraquara, v. 22, n. esp.1, p. 105-136, mar., 2018. 
que participem ativamente de sua própria educação e dela se beneficiem. Os conhecimentos e as habilidades necessários à ampliação das condições de aprendizagem das crianças devem estar integrados aos programas de educação comunitária para adultos. A educação das crianças e a de seus pais ou responsáveis respaldam-se mutuamente, e esta interação deve ser usada para criar, em benefício de todos, um ambiente de aprendizagem onde haja calor humano e vibração.

O Marco de Ação de Dakar, na primeira meta proposta, enfatiza o cuidado e a educação da criança pequena, a qual é atendida em nosso sistema educacional na Educação Infantil, primeira etapa da Educação Básica. De acordo com o documento, "Todas as criancas pequenas devem ser criadas em ambientes seguros e amigáveis que lhes permitam tornar-se saudáveis, ativas e confiantes e ser capazes de aprender" (UNESCO, CONSED, 2001, p. 18).

Segundo o PNEDH a escola é “[...] um espaço social privilegiado onde se definem a prática e a vivência dos direitos humanos [...], de concepções de mundo e de consciência social, de circulação e de consolidação de valores, de promoção da diversidade cultural, da formação para a cidadania, da constituição de sujeitos sociais [...]. (BRASIL, 2007, p. 31). O Parecer CNE/CEB No 7/2010 contextualiza a importância dos ambientes de aprendizagem na seguinte perspectiva:

Construir a qualidade social pressupõe conhecimento dos interesses sociais da comunidade escolar para que seja possível educar e cuidar mediante interação efetivada entre princípios e finalidades educacionais, objetivos, conhecimento e concepções curriculares. Isso abarca mais que o exercício político-pedagógico que se viabiliza mediante atuação de todos os sujeitos da comunidade educativa. $\mathrm{Ou}$ seja, efetiva-se não apenas mediante participação de todos os sujeitos da escola - estudante, professor, técnico, funcionário, coordenador mas também mediante aquisição e utilização adequada dos objetos e espaços (laboratórios, equipamentos, mobiliário, salas-ambiente, biblioteca, videoteca etc.) requeridos para responder ao projeto político-pedagógico pactuado, vinculados às condições/disponibilidades mínimas para se instaurar a primazia da aquisição e do desenvolvimento de hábitos investigatórios para construção do conhecimento.

$\mathrm{O}$ ambiente educacional pode se constituir num facilitador ou num entrave ao desenvolvimento integral dos estudantes. O ambiente, compreendido como composto pelos espaços físicos organizados para a promoção da aprendizagem e as relações interpessoais que se estabelecem neles, reflete a concepção de educação, as práticas educativas e os valores de determinada escola. Dessa forma, um ambiente acolhedor, 
estruturado dentro dos parâmetros da sustentabilidade e da segurança, onde o diálogo e o respeito mútuo preponderam, contribui para o bem-estar e o desenvolvimento das potencialidades. Nessa linha reflexiva, Libâneo, Oliveira e Toschi (2003, p. 296) asseveram que

\begin{abstract}
As escolas são, pois, ambientes formativos, o que significa que as práticas de organização e de gestão educam, isto é, podem criar ou modificar os modos de pensar e agir das pessoas. Por outro lado, também a organização escolar aprende com as pessoas, uma vez que sua estrutura e seus processos de gestão podem ser construídos pelos próprios membros que as compõem.
\end{abstract}

Segundo Lück (2009, p. 21), o ambiente escolar “[...] é considerado de vital importância para o desenvolvimento de aprendizagens significativas que possibilitem aos alunos conhecerem o mundo e conhecerem-se no mundo, como condição para o desenvolvimento de sua capacidade de atuação cidadã". Dessa forma, "A qualidade do ambiente escolar como um todo determina a qualidade do processo pedagógico da sala de aula" (Ibidem).

\title{
d) Existência de um projeto político-pedagógico alicerçado em valores humanistas
}

A ação gestora pressupõe a observação de vários tipos de documentos que requerem planejamento e construção coletivos, sendo que aos gestores compete a coordenação da elaboração (ou revitalização) desses documentos. Lück (2009, p. 32) alude que

\begin{abstract}
Planejar a educação e a sua gestão implica em delinear e tornar clara e entendida em seus desdobramentos a sua intenção, os seus rumos, os seus objetivos, a sua abrangência e as perspectivas de sua atuação, além de organizar, de forma articulada, todos os aspectos necessários para a sua efetivação. Para tanto, o planejamento envolve, antes de tudo, uma visão global e abrangente sobre a natureza da Educação, da gestão escolar e suas possibilidades de ação.
\end{abstract}

A LDB/96 estabelece como uma das responsabilidades dos estabelecimentos de ensino "elaborar e executar sua proposta pedagógica” (BRASIL, 1996). A Proposta Pedagógica (ou Projeto Político-Pedagógico) é um dispositivo que condensa o ideário educativo, confere identidade, orienta a organização e as ações educativas, tal como aponta Vasconcelos (2004). O PPP deve ser compreendido como um dispositivo que necessita ser revitalizado continuamente, e sendo assim

RPGE - Revista on line de Política e Gestão Educacional, Araraquara, v. 22, n. esp.1, p. 105-136, mar., 2018. 
Pode ser entendido como a sistematização, nunca definitiva, de um processo de planejamento participativo, que se aperfeiçoa e se concretiza na caminhada, que define claramente o tipo de ação educativa que se quer realizar. É um instrumento teórico metodológico para a intervenção e mudança da realidade. É um elemento de organização e integração da atividade prática da instituição neste processo de transformação. (VASCONCELOS, 2004, p. 169).

O PNEDH (Brasil, 2007, p. 32) assevera que "a educação em direitos humanos deve ser um dos eixos fundamentais da Educação Básica e permear o currículo, a formação inicial e continuada dos profissionais da educação, o Projeto PolíticoPedagógico da escola, os materiais didático-pedagógicos, o modelo de gestão e a avaliação". No que se refere à organização curricular das instituições de ensino, os conhecimentos relativos à Educação em Direitos Humanos poderão ser abordados por meio de temas transversais tratados de forma interdisciplinar; como conteúdo específico de algum componente curricular já existente no currículo; ou "de maneira mista, ou seja, combinando transversalidade e disciplinaridade" (BRASIL, 2012). O Art. $6^{\circ}$ das Diretrizes Nacionais para a Educação em Direitos Humanos estabelece que:
A Educação em Direitos Humanos, de modo transversal, deverá ser considerada na construção dos Projetos Político-Pedagógicos (PPP); dos Regimentos Escolares; [...]dos materiais didáticos e pedagógicos; do modelo de ensino; [...] de gestão, bem como dos diferentes processos de avaliação.

O objetivo da Educação em Direitos Humanos é "a formação para a vida e para a convivência, no exercício cotidiano dos direitos humanos como forma de vida e de organização social, política, econômica e cultural nos níveis regional, nacional e planetário" (BRASIL, 2012). Com base nesses princípios fundamentais, são propostas as seguintes dimensões:

I - apreensão de conhecimentos historicamente construídos sobre direitos humanos e a sua relação com os contextos internacional, nacional e local;

II - afirmação de valores, atitudes e práticas sociais que expressem a cultura dos direitos humanos em todos os espaços da sociedade;

III - formação de uma consciência cidadã capaz de se fazer presente em níveis cognitivo, social, cultural e político;

IV - desenvolvimento de processos metodológicos participativos e de construção coletiva, utilizando linguagens e materiais didáticos contextualizados; e 
$\mathrm{V}$ - fortalecimento de práticas individuais e sociais que gerem ações e instrumentos em favor da promoção, da proteção e da defesa dos direitos humanos, bem como da reparação das diferentes formas de violação de direitos. (BRASIL, 2012).

Diante do exposto, "Os gestores precisam trabalhar com os professores a concepção de escola que desejam implementar e, de acordo com essa concepção como se definirá o projeto pedagógico da escola e a prática de seus professores, de maneira a promover a aprendizagem contínua dos alunos" (DAVIS, GROSBAUM, 2002, p. 77 78).

e) Prática pedagógica pautada pelos princípios da liberdade, da igualdade, da equidade e da diversidade

A educação, como meio para o alcance dos outros direitos humanos, pressupõe que o contexto escolar seja propício à reflexão sobre a dignidade humana, oportunizando a participação, o exercício da cidadania e o desenvolvimento da autonomia da comunidade educativa. Segundo o Parecer CNE/CEB No 7/2010, “A escola de qualidade social adota como centralidade o diálogo, a colaboração, os sujeitos e as aprendizagens", tendo presente os seguintes aspectos:

I - revisão das referências conceituais quanto aos diferentes espaços e tempos educativos, abrangendo espaços sociais na escola e fora dela; II - consideração sobre a inclusão, a valorização das diferenças e o atendimento à pluralidade e à diversidade cultural, resgatando e respeitando os direitos humanos, individuais e coletivos e as várias manifestações de cada comunidade; III - foco no projeto políticopedagógico, no gosto pela aprendizagem, e na avaliação das aprendizagens como instrumento de contínua progressão dos estudantes; IV - inter-relação entre organização do currículo, do trabalho pedagógico e da jornada de trabalho do professor, tendo como foco a aprendizagem do estudante; V - preparação dos profissionais da educação, gestores, professores, especialistas, técnicos, monitores e outros; VI - compatibilidade entre a proposta curricular e a infraestrutura entendida como espaço formativo dotado de efetiva disponibilidade de tempos para a sua utilização e acessibilidade; VII - integração dos profissionais da educação, os estudantes, as famílias, os agentes da comunidade interessados na educação; VIII - valorização dos profissionais da educação, com programa de formação continuada, critérios de acesso, permanência, remuneração compatível com a jornada de trabalho definida no projeto político-pedagógico; IX - realização de parceria com órgãos, tais como os de assistência social, desenvolvimento e direitos humanos, cidadania, ciência e tecnologia, esporte, turismo, cultura e arte, saúde, meio ambiente.

RPGE - Revista on line de Política e Gestão Educacional, Araraquara, v. 22, n. esp.1, p. 105-136, mar., 2018. 
No entender de Penin e Vieira (2002, p. 13), as relações que se efetivam na escola “[...] imprimem marcas naqueles que por ela transitam. Se estas relações são permeadas por princípios democráticos - respeito ao outro, solidariedade, liberdade -, as pessoas crescem no aprendizado e no exercício da democracia”. Lück (2009, p. 19) explica que "Como um processo social de formação humana, a educação se assenta sobre fundamentos, princípios e diretrizes para norteá-lo e dar unidade e consistência às ações educacionais promovidas pelas escolas".

\title{
f) Desenvolvimento de competências
}

Ao falarmos em competência, partimos do pressuposto de que ela é decorrente da mobilização de um conjunto de conhecimentos, habilidades, atitudes e valores, contemplando também o desenvolvimento da espiritualidade. O Marco de Ação de Dakar, em sua terceira meta sobre as necessidades de aprendizagem de todos os jovens $e$ adultos, salienta que todos devem ter a oportunidade de construir conhecimentos e desenvolver competências "para trabalho, para participar plenamente de sua sociedade, para deter o controle de sua própria vida e para continuar aprendendo" (UNESCO, CONSED, 2001, p. 19). Diante disso, o documento assevera que: “A todos [...] deve ser dada a oportunidade de obter conhecimento e desenvolver valores, atitudes e habilidades que lhes possibilitem melhorar suas capacidades para o trabalho, para participar plenamente de sua sociedade, para deter o controle de sua própria vida e para continuar aprendendo".

O PNEDH também salienta o desenvolvimento de conhecimentos, habilidades, valores e atitudes, quais sejam:

\begin{abstract}
a) conhecimentos e habilidades: compreender os direitos humanos e os mecanismos existentes para a sua proteção, assim como incentivar o exercício de habilidades na vida cotidiana; b) valores, atitudes e comportamentos: desenvolver valores e fortalecer atitudes e comportamentos que respeitem os direitos humanos; c) ações: desencadear atividades para a promoção, defesa e reparação das violações aos direitos humanos. (BRASIL, 2007, p. 32)
\end{abstract}

Nessa perspectiva, segundo a Declaração de Incheon, a educação de qualidade proporciona habilidades, valores e atitudes que tornam a pessoa apta a viver a vida em sua plenitude, tomando decisões pensadas e respondendo com consciência os desafios locais e globais (UNESCO, 2015). 


\section{g) Promoção da aprendizagem}

A Declaração Mundial sobre Educação para Todos (UNESCO, 1990) enfatiza que: "Cada pessoa - criança, jovem ou adulto - deve estar em condições de aproveitar as oportunidades educativas voltadas para satisfazer suas necessidades básicas de aprendizagem". Explica o documento:

Essas necessidades compreendem tanto os instrumentos essenciais para a aprendizagem (como a leitura e a escrita, a expressão oral, o cálculo, a solução de problemas), quanto os conteúdos básicos da aprendizagem (como conhecimentos, habilidades, valores e atitudes) necessários para que os seres humanos possam sobreviver, desenvolver plenamente suas potencialidades, viver e trabalhar com dignidade, participar plenamente do desenvolvimento, melhorar a qualidade de vida, tomar decisões fundamentadas e continuar aprendendo. A amplitude das necessidades básicas de aprendizagem e a maneira de satisfazê-las variam segundo cada país e cada cultura, e, inevitavelmente, mudam com o decorrer do tempo.

Reforçando a proposição da Declaração Mundial sobre Educação para Todos, o Marco de Ação de Dakar enfatiza que

A qualidade está no cerne da educação e o que tem lugar nas salas de aula e em outros ambientes de aprendizagem é fundamentalmente importante para o bem-estar futuro das crianças, jovens e adultos. Educação de qualidade é aquela que satisfaz as necessidades básicas de aprendizagem e enriquece a vida dos educandos e sua experiência global de vida. (UNESCO; CONSED; AÇÃO EDUCATIVA, 2001, p. 20)

O Parecer CNE/CEB No 7/2010 reitera que "Somente um ser educado terá condição efetiva de participação social, ciente e consciente de seus direitos e deveres civis, sociais, políticos, econômicos e éticos". Por isso, considera que o estudante se constitui na centralidade da Educação Básica, sendo “oportuno e necessário considerar as dimensões do educar e do cuidar, em sua inseparabilidade". Continua o documento:

Cuidar e educar significa compreender que o direito à educação parte do princípio da formação da pessoa em sua essência humana. Trata-se de considerar o cuidado no sentido profundo do que seja acolhimento de todos - crianças, adolescentes, jovens e adultos - com respeito e, com atenção adequada, de estudantes com deficiência, jovens e adultos defasados na relação idade-escolaridade, indígenas, afrodescendentes, quilombolas e povos do campo. (BRASIL, 2010).

RPGE - Revista on line de Política e Gestão Educacional, Araraquara, v. 22, n. esp.1, p. 105-136, mar., 2018. 
Dessa forma, confome exposto, o direito à educação articula-se na possibilidade de cada pessoa poder ter êxito em termos de aprendizagem e ao seu pleno desenvolvimento. Assim, não basta ter o acesso garantido à educação; é fundamental a existência de mecanismos que viabilizem a permanência e o sucesso escolar. Na equipe de gestão escolar, a supervisão escolar tem como uma de suas tarefas o acompanhamento do corpo docente de forma que suas práticas educativas possam ser compatíveis com a demanada dos estudantes, considerando suas peculiaridades, necessidades e ritmos de aprendizagem. A educação, e em decorrência a aprendizagem ao longo da vida, é foco da Declaração de Incheon (UNESCO, 2015), defendendo que vidas podem ser transformadas por meio da garantia de educação de qualidade equitativa e inclusiva. A Declaração de Incheon, ao projetar a educação até o ano de 2030, salienta o compromisso assumido com

[...] a educação de qualidade e com a melhoria dos resultados de aprendizagem, o que exige o reforço de insumos e processos, além da avaliação de resultados de aprendizagem e de mecanismos para medir o progresso. Garantiremos que professores e educadores sejam empoderados, recrutados adequadamente, bem treinados, qualificados profissionalmente, motivados e apoiados em sistemas que disponham de bons recursos e sejam eficientes e dirigidos de maneira eficaz. A educação de qualidade promove criatividade e conhecimento, e também assegura a aquisição de habilidades básicas em alfabetização e matemática, bem como habilidades analíticas e de resolução de problemas, habilidades de alto nível cognitivo e habilidades interpessoais e sociais. Além disso, ela desenvolve habilidades, valores e atitudes que permitem aos cidadãos levar vidas saudáveis e plenas, tomar decisões conscientes e responder a desafios locais e globais por meio da educação para o desenvolvimento sustentável (EDS) e da educação para a cidadania global. (ECG). (UNESCO, 2015).

O documento alude à questão da qualidade, apresentando alguns indicativos:

Uma parte integrante do direito à educação é garantir que a educação tenha qualidade suficiente para gerar resultados de aprendizagem relevantes, equitativos e eficientes em todos os níveis e contextos. Uma educação de qualidade requer, no mínimo, que os alunos desenvolvam habilidades básicas em leitura, escrita e matemática como fundamento para a aprendizagem futura, bem como para habilidades mais complexas. Isso requer métodos e conteúdos relevantes de ensino e aprendizagem, que atendam às necessidades de todos os alunos, com professores bem qualificados, treinados, motivados e bem pagos, que usem abordagens pedagógicas adequadas e apoiem-se em tecnologias da informação e comunicação (TIC) apropriadas. Requer, ainda, a criação de ambientes seguros, saudáveis, 
responsivos a gênero, inclusivos e devidamente equipados, que facilitem a aprendizagem. $\mathrm{O}$ direito à educação começa no nascimento e continua ao longo da vida; portanto, o conceito de aprendizagem ao longo da vida guia a Educação 2030. Para complementar e suplementar a escolarização formal, devem ser oferecidas oportunidades amplas e flexíveis de aprendizagem ao longo da vida, por meio de caminhos não formais, com recursos e mecanismos adequados, e também por meio do estímulo à aprendizagem informal, inclusive pelo uso das TIC. (UNESCO, 2015b, grifo do documento).

Portanto, relacionado à ideia da educação de qualidade como um direito está o direito à aprendizagem. Ou seja, é necessário assegurar que as crianças, jovens e adultos desenvolvam as competências necessárias para a sua constituição enquanto cidadãos e sujeitos ativos dentro do contexto no qual se encontram inseridos.

\section{h) Avaliação da qualidade educacional}

A sexta meta proposta pelo Marco de Ação de Dakar refere a melhoria dos aspectos da qualidade da educação, visando assegurar excelência para todos. Para tanto, os estados devem trabalhar juntos para assegurar

[...] educação fundamental de qualidade para todos, independentemente de gênero, riqueza, local, língua ou origem étnica: (1) alunos saudáveis, bem nutridos e motivados; (2) professores bem capacitados e técnicas de ensino ativas; (3) instalações e materiais didáticos adequados; (4) currículo pertinente que possa ser ensinado e aprendido na língua local e se apoie nos conhecimentos e experiências dos professores e alunos; (5) ambientes que não só estimulem a aprendizagem, mas também sejam acolhedores, sadios e seguros, e levem em conta os gêneros; (6) definição clara e avaliação precisa dos resultados da aprendizagem, que incluam conhecimentos, habilidades atitudes e valores; (7) governo e administração participativos; (8) respeito pelas comunidades e culturas locais e envolvimento nelas. (UNESCO; CONSED, 2001, p. 20-21).

Nas últimas décadas a aferição do desempenho dos estudantes tem se acentuado, considerando-se que o cumprimento das metas estabelecidas e acordadas mundialmente por meio dos dispositivos legais, relativas à educação de qualidade, requer monitoramento sistemático. No que se refere à avaliação da qualidade, o Parecer $\mathrm{CNE} / \mathrm{CEB}$ n$^{\circ} 7 / 2010$ esclarece que tal avaliação precisa estar articulada à ação pautada pelo planejamento coletivo no contexto escolar e que "os sujeitos tenham clareza" quanto

RPGE - Revista on line de Política e Gestão Educacional, Araraquara, v. 22, n. esp.1, p. 105-136, mar., 2018. 
I - aos princípios e às finalidades da educação, além do reconhecimento e análise dos dados indicados pelo IDEB e/ou outros indicadores, que complementem ou substituam estes; II - à relevância de um projeto político-pedagógico concebido e assumido coletivamente pela comunidade educacional, respeitadas as múltiplas diversidades e a pluralidade cultural; III - à riqueza da valorização das diferenças manifestadas pelos sujeitos do processo educativo, em seus diversos segmentos, respeitados o tempo e o contexto sociocultural; IV - aos padrões mínimos de qualidade que apontam para quanto deve ser investido por estudante de cada etapa e modalidade da Educação Básica, para que o país ofereça educação de qualidade a todos os estudantes.

No PNE, a avaliação da qualidade da Educação Básica é focada no Art. 11, enfatizando o Sistema Nacional de Avaliação da Educação Básica que, no máximo a cada dois anos, produzirá:

I - indicadores de rendimento escolar, referentes ao desempenho dos(as) estudantes, apurado em exames nacionais de avaliação, com participação de pelo menos oitenta por cento dos(as) alunos(as) de cada ano escolar periodicamente avaliado em cada escola, e aos dados pertinentes apurados pelo censo escolar da Educação Básica;

II - indicadores de avaliação institucional, relativos a características como o perfil do alunado e do corpo dos(as) profissionais da educação, as relações entre dimensão do corpo docente, do corpo técnico e do corpo discente, a infraestrutura das escolas, os recursos pedagógicos disponíveis e os processos da gestão, entre outras relevantes. (BRASIL, 2014).

A meta 7 do PNE tem como foco o fomento da Educação Básica, com melhoria do fluxo escolar e da aprendizagem, com vistas a atingir até 2012 as médias nacionais para o Índice de Desenvolvimento da Educação Básica (IDEB) (BRASIL, 2014). Assim como o Brasil, outros países da América Latina, tais como o Chile, a Colômbia, a Argentina, o Equador, dentre outros, também criaram sistemas de avaliação externa próprios, visando ao monitoramento da qualidade educacional em seus sistemas e redes de ensino (BONAMINO, 2002). No Brasil, "as políticas públicas educacionais apresentam questões relacionadas à implementação da avaliação como perspectiva de uma nova função do Estado, para assegurar a participação da sociedade no acompanhamento dos processos educativos. Portanto, as avaliações externas são compreendidas como necessidade e direito social”. (SANTOS; GIMENESES; MARIANO, 2013, p. 42). Conforme assinala Lück (2009, p. 44), 
Verifica-se que o monitoramento e a avaliação em educação, embora constituam-se em processos essenciais da sua gestão, não são práticas comuns em escolas e apenas recentemente estão sendo adotados como práticas na gestão de sistemas de ensino. Aliás, estranhamente, apesar de seu caráter de "feedback" necessário ao trabalho educacional, a referência à sua possível instituição nas escolas provoca entre seus profissionais fortes reações e até mesmo resistência. Talvez porque sejam atribuídos significados inadequados a eles: o monitoramento é visto como um controle cerceador e limitador, portanto, negativo, e a avaliação como uma estratégia de encontrar erros e causar reprovações. Sugerimos a proposta que esse entendimento pode ter mais a ver com o modo como a avaliação é praticada nas escolas do que como seu real significado pedagógico. (LUCK, 2009, p.44).

Corroboramos a posição de Davis e Grosbaum (2002, p. 110-111), quando as autoras referem que

[...] a avaliação deve ser vista como instrumento importante da gestão escolar. Ela mostra os pontos frágeis do ensino ministrado aos alunos, permitindo que novas formas de ensinar sejam construídas. Auxilia na identificação dos docentes que estão precisando de atualização profissional e pode subsidiar as metas que a escola se propõe alcançar no projeto pedagógico. Usada dessa forma, ela é tanto tarefa pedagógica como administrativa, atividade capaz de promover o sucesso da aprendizagem e a permanência bem sucedida de todos os alunos na escola.

Diante do exposto, é possível perceber que a avaliação dos resultados educacionais por meio de mecanismos de avaliação externa tem sido alvo de diferentes tipos de críticas, pautando-se na justificativa, dentre outras, que esta tipologia de avaliação é um instrumento de controle e que desconsidera as características e as peculiaridades de cada contexto educativo e de seus alunos. Entretanto, apesar de limitações que são inerentes a qualquer processo e instrumento que objetiva a avaliação interna ou externa (seja ela da aprendizagem, do desempenho docente e/ou da instituição), entendemos que cada tipologia de avaliação possui objetivos e finalidades distintas. A avaliação, como qualquer outro procedimento dentro do processo educativo, não é neutra e está relacionada às concepções que cada um possui a seu respeito. Assim, "é preciso que haja clareza sobre o que entendemos por avaliação, suas metas e finalidades" (DAVIS; GROSBAUM, 2002, p. 105).

\section{i) Formação, qualificação profissional e valorização dos profissionais da educação}

Já é consenso que a melhoria da qualidade da educação está relacionada à qualidade da formação dos professores (inicial e continuada); às condições de trabalho;

RPGE - Revista on line de Política e Gestão Educacional, Araraquara, v. 22, n. esp.1, p. 105-136, mar., 2018. 
à motivação destes profissionais no exercício da docência; ao reconhecimento profissional pela comunidade escolar onde atua e pela própria sociedade, enquanto um todo; à sua valorização expressa através de remuneração digna. O Plano Nacional de Educação 2014-2024 propõe ações pautadas em princípios constitucionais, estabelecendo a valorização dos profissionais da educação como uma de suas diretrizes (BRASIL, 2014). No que se refere à formação inicial e continuada, são propostas as seguintes metas:

Meta 15. Garantir, em regime de colaboração entre a União, os estados, o Distrito Federal e os municípios, no prazo de um ano de vigência deste PNE, política nacional de formação dos profissionais da educação de que tratam os incisos I, II e III do caput do art. 61 da Lei $\mathrm{n}^{\circ}$ 9.394, de 20 de dezembro de 1996, assegurado que todos os professores e as professoras da Educação Básica possuam formação específica de nível superior, obtida em curso de licenciatura na área de conhecimento em que atuam.

Meta 16. Formar, em nível de pós-graduação, cinquenta por cento dos professores da Educação Básica, até o último ano de vigência deste PNE, e garantir a todos(as) os(as) profissionais da Educação Básica formação continuada em sua área de atuação, considerando as necessidades, demandas e contextualizações dos sistemas de ensino.

A valorização profissional, compreendendo a equiparação salarial e o plano de carreira, é focalizada nas metas 17 e 18 do PNE:

Meta 17. Valorizar os(as) profissionais do magistério das redes públicas de Educação Básica, de forma a equiparar seu rendimento médio ao dos(as) demais profissionais com escolaridade equivalente, até o final do sexto ano de vigência deste PNE.

Meta 18. Assegurar, no prazo de dois anos, a existência de planos de carreira para os(as) profissionais da Educação Básica e Superior pública de todos os sistemas de ensino e, para o plano de carreira dos(as) profissionais da Educação Básica pública, tomar como referência o piso salarial nacional profissional, definido em lei federal, nos termos do inciso VIII do art. 206 da Constituição Federal.

A oferta de educação de qualidade, dentre outros aspectos, pressupõe que os profissionais da educação, especialmente os professores, possuam formação e qualificação profissionais, pois são eles que estão à frente do processo educativo no cotidiano escolar. O corpo docente constitui a "alma da escola e a base da sua qualidade educacional [...] são as pessoas, trabalhando em conjunto, de forma integrada, compartilhando competentemente responsabilidades, que fazem a diferença na qualidade do trabalho" (LUCK, 2009, p.82). No entender de Libâneo, Oliveira e Toschi 
(2003, p. 36-37), “[...] a formação geral de qualidade dos alunos depende da qualidade da formação dos professores". Ao falarmos em formação docente, temos presente a formação inicial e a continuada. Ao projetar esses espaços e tempos formativos é importante que a equipe de gestão esteja atenta às reais demandas formativas do corpo docente, de forma que seja possível contribuir efetivamente para a qualificação profissional. Trazemos à tona a reflexão de Nóvoa:

Grande parte dos programas de formação contínua tem-se revelado de grande inutilidade, servindo apenas para complicar um quotidiano docente já de si fortemente exigente. Os professores devem recusar o consumismo de cursos, seminários e acções que caracteriza o "mercado da formação" e que alimenta um sentimento de "desactualização" dos professores. A concepção da Educação Permanente obriga-nos a pensar ao contrário, construindo os dispositivos de formação a partir das necessidades das pessoas e da profissão, investindo na construção de redes de trabalho colectivo que sejam o suporte de práticas de formação baseadas na partilha e no diálogo profissional. (NÓVOA, 2007, p. 9, grifo do autor).

A educação de qualidade passa também pela qualidade da gestão escolar. Portanto, aqueles que estão à frente dessa gestão necessitam ter o domínio sobre um conjunto de conhecimentos específicos para exercer de forma efetiva tal função. Assim, "Nenhuma escola pode ser melhor do que os profissionais que nela atuam. Nem o ensino pode ser democrático, isto é, de qualidade para todos, caso não se assente sobre padrões de qualidade e competências profissionais básicas que sustentem essa qualidade" (LÜCK, 2009, p. 12).

\section{Considerações finais}

As reflexões apresentadas ao longo do texto nos remetem à ideia de que a efetivação do direito à educação de qualidade, assim como afirma o Parecer CNE/CEB No 7/2010, “[...] não é viabilizada por decreto, resolução, portaria ou similar, ou seja, não se efetiva tão somente por meio de prescrição de atividades de ensino ou de estabelecimento de parâmetros ou diretrizes curriculares: a educação de qualidade social é conquista e, como conquista da sociedade brasileira, é manifestada pelos movimentos sociais, pois é direito de todos". Continua o documento:

O desafio posto pela contemporaneidade à educação é o de garantir, contextualizadamente, o direito humano universal e social inalienável

RPGE - Revista on line de Política e Gestão Educacional, Araraquara, v. 22, n. esp.1, p. 105-136, mar., 2018. 
à educação. $\mathrm{O}$ direito universal não é passível de ser analisado isoladamente, mas deve sê-lo em estreita relação com outros direitos, especialmente dos direitos civis e políticos e dos direitos de caráter subjetivo, sobre os quais incide decisivamente. Compreender e realizar a educação, entendida como um direito individual humano e coletivo, implica considerar o seu poder de habilitar para o exercício de outros direitos, isto é, para potencializar o ser humano como cidadão pleno, de tal modo que este se torne apto para viver e conviver em determinado ambiente, em sua dimensão planetária. A educação é, pois, processo e prática que se concretizam nas relações sociais que transcendem o espaço e o tempo escolares, tendo em vista os diferentes sujeitos que a demandam. (grifo do documento).

Com base no que preconizam os dispositivos analisados, entre os desafios que se colocam à gestão escolar para a oferta de educação de qualidade, destacam-se: a gestão democrática; o desenvolvimento da cultura dos direitos humanos; a estruturação de ambientes de aprendizagem seguros e saudáveis; a existência de um projeto políticopedagógico alicerçado em valores humanistas; a prática pedagógica pautada pelos princípios da liberdade, da igualdade, da equidade e da diversidade; o desenvolvimento de competências; a promoção da aprendizagem; a avaliação da qualidade educacional; a formação, a qualificação profissional e a valorização dos profissionais da educação. Por fim, corroboramos a posição de Vieira (2006, p. 28): “uma gestão escolar bem-sucedida, portanto, é aquela voltada para a aprendizagem de todos os alunos”.

\section{REFERÊNCIAS}

APPOLINÁRIO, Fábio. Dicionário de metodologia científica: um guia para a produção do conhecimento científico. São Paulo, Atlas, 2009.

BARDIN, Laurence. Análise de conteúdo. São Paulo: Edições 70, 2011.

BONAMINO, Alicia C. Tempos de avaliação educacional: o SAEB, seus agentes, referências e tendências. Rio de Janeiro: Quarteto Editora \& Comunicação Ltda., 2002.

BRASIL. Constituição da República Federativa do Brasil. Brasília-DF: Senado Federal, 1988.

BRASIL. Decreto No 99.710 , de 21 de novembro de 1990. Promulga a Convenção sobre os Direitos da Criança. Diário Oficial da União, Brasília-DF, 1990.

BRASIL. Lei no 8.069, de 13 de julho de 1990. Dispõe sobre o Estatuto da Criança e do Adolescente e dá outras providências, 1990 b. 
BRASIL. Lei no 9.394, de 20 de dezembro de 1996. Estabelece as diretrizes e bases da educação nacional. Diário Oficial [da] República Federativa do Brasil, Brasília-DF, 1996.

BRASIL. Ministério da Educação. Secretaria de Educação Fundamental. Parâmetros curriculares nacionais: apresentação dos temas transversais. Brasília-DF: MEC/SEF, 1997.

BRASIL. Portaria n⿳0 931, de 21 de março de 2005: institui o Sistema de Avaliação da Educação Básica. Diário Oficial [da] República Federativa do Brasil, Brasília-DF, seção 1, 22 mar. 2005.

BRASIL. Presidência da República. Casa Civil. Subchefia para Assuntos Jurídicos. Lei $\mathbf{n}^{\mathbf{0}} \mathbf{1 1 2 7 4}$, de 6 de fevereiro de 2006. Altera a redação dos arts. 29, 30, 32 e 87 da Lei $\mathrm{n}^{\circ}$ 9.394, de 20 de dezembro de 1996, que estabelece as diretrizes e bases da educação nacional, dispondo sobre a duração de 9 (nove) anos para o ensino fundamental, com matrícula obrigatória a partir dos 6 (seis) anos de idade.

BRASIL. Plano de Desenvolvimento da Educação. Brasília: Ministério da Educação, 2007a.

BRASIL. Decreto no 6.094, de 24 de abril de 2007. Dispõe sobre a implementação do Plano de Metas Compromisso Todos pela Educação, pela União Federal. Diário Oficial da União, Brasília-DF, 25 abr. 2007b.

BRASIL. Comitê Nacional de Educação em Direitos Humanos. Plano Nacional de Educação em Direitos Humanos - Comitê Nacional de Educação em Direitos Humanos. - Brasília: Secretaria Especial dos Direitos Humanos, Ministério da Educação, Ministério da Justiça, UNESCO, 2007c.

BRASIL. Parecer CNE/CEB n⿳0 7/2010. Despacho do Ministro, publicado no D.O.U. de 9/7/2010, Seção 1, p.10.

BRASIL. Presidência da República. Casa Civil. Subchefia para assuntos jurídicos. Decreto n⿳ 7.083, de 27 de janeiro de 2010. Dispõe sobre o Programa mais Educação.

BRASIL. Portaria $\mathbf{n}^{\circ}$ 867, de 4 de julho de 2012. Institui o Pacto Nacional pela Alfabetização na Idade Certa, 2012a.

BRASIL. Ministério da Educação. Conselho Nacional de Educação. Resolução no 1, de 30 de maio de 2012. Estabelece Diretrizes Nacionais para a Educação em Direitos Humanos, 2012b.

BRASIL. Ministério da Educação. Diretrizes Curriculares Nacionais Gerais da Educação Básica. Brasília: MEC, SEB, DICEI, 2013.

BRASIL. Presidência da República. Casa Civil. Subchefia para assuntos jurídicos. Lei $\mathbf{n}^{0}$ 13.005, de 25 de junho de 2014. Aprova o Plano Nacional de Educação-PNE e dá outras providências, 2014.

RPGE - Revista on line de Política e Gestão Educacional, Araraquara, v. 22, n. esp.1, p. 105-136, mar., 2018. 
DAVIS, Cláudia.; GROSBAUM, Marta W. Sucesso de todos, compromisso da escola. IN: VIEIRA, Sofia Lerche (Org.). Gestão da escola: desafios a enfrentar. São Paulo: DP\&A, 2002. p. 77-112.

DELORS, Jacques. Educação ou a utopia necessária. IN: DELORS, Jacques et al. Educação: Um tesouro a descobrir. Relatório para a UNESCO da Comissão Internacional sobre Educação para o século XXI. Brasília: UNESCO, 2010, p. 1-25.

FLICK, Uwe. Introdução à pesquisa qualitativa. 3 ed. Porto Alegre: Artmed, 2009.

GODOY, Arilda S. Pesquisa qualitativa: tipos fundamentais. Revista Administração de Empresas. 1995, v. 35, n. 3, p. 20-29.

LIBÂNEO, José C.; OLIVEIRA, João Ferreira de; TOSCHI, Mirza Seabra. Educação escolar: políticas, estrutura e organização. São Paulo: Cortez, 2003.

LÜCK, H. Dimensões de gestão escolar e suas competências. Curitiba: Editora Positivo, 2009.

MEDEIROS, Isabel L. P. de.; LUCE, Maria Beatriz. Gestão Democrática na e da educação: concepções e vivências. IN: LUCE, Maria Beatriz; MEDEIROS, Isabel Letícia Pedroso de (Org.). Gestão escolar democrática: concepções e vivências. Porto Alegre: Ed. da UFRGS, 2006, p. 15- 25.

NÓVOA, António. Formação de Professores e Qualidade do Ensino. Aprendizagem, $\mathrm{n}^{\mathbf{0}}$ 2, Paraná, p. 25-31, set./out., 2007.

ORGANIZAÇÃO DAS NAÇÕES UNIDAS PARA A EDUCAÇÃO, A CIÊNCIA E A CULTURA - UNESCO. Declaração Mundial sobre Educação para Todos: satisfação das necessidades básicas de aprendizagem. Jomtien, 1990.

ORGANIZAÇÃO DAS NAÇÕES UNIDAS PARA A EDUCAÇÃO, A CIÊNCIA E A CULTURA - UNESCO. Declaração de Incheon - Educação 2030: Rumo a uma educação de qualidade inclusiva e à educação ao longo da vida para todos. UNESCO, 2015a.

ORGANIZAÇÃO DAS NAÇÕES UNIDAS PARA A EDUCAÇÃO, A CIÊNCIA E A CULTURA - UNESCO. Marco de Ação - Educação 2030: Rumo a uma educação de qualidade inclusiva e à educação ao longo da vida para todos. UNESCO, 2015b.

ORGANIZAÇÃO DAS NAÇÕES UNIDAS PARA A EDUCAÇÃO, A CIÊNCIA E A CULTURA - UNESCO. CONSED, AÇÃO EDUCATIVA. Educação para Todos: o Compromisso de Dakar. Brasília: Unesco, Consed, Ação Educativa, 2001.

\section{ORGANIZAÇÃO DAS NAÇÕES UNIDAS-ONU. Declaração Universal dos} Direitos Humanos, 1948.

PÁDUA, Elisabete M. M. Metodologia de pesquisa: Abordagem teórico-prática. Campinas: Papirus, 2004. 
PENIN, Sonia T. Sousa; VIEIRA, Sofia Lerche. Refletindo sobre a função social da escola. In: VIEIRA, Sofia Lerche (Org.). Gestão da escola - desafios a enfrentar. Rio de Janeiro: DP\&A, 2002. p. 13 a 45.

SANTOS, Anderson Oramísio; GIMENESES, Olíria Mendes; MARIANO, Sangelita M. Franco. Avaliações Externas e seus impactos nas Práticas Pedagógicas: percepções e visões preliminares. Revista Encontro de Pesquisa em Educação Uberaba, v. 1, n.1, p. 38-50, 2013.

VASCONCELLOS, Celso S. Projeto político-pedagógico: educação superior. Campinas: Papirus, 2004.

\section{Como referenciar este artigo}

MENEGAT, Jardelino.; SARMENTO, Dirlea Fanfa.; RANGEL, Mary. O direito à educação de qualidade e suas decorrências para a gestão escolar. Revista on line de Política e Gestão Educacional, Araraquara, v. 22, n. esp.1, p. 105-136, mar., 2018. EISSN:1519-9029.

Submetido em: 04/10/2017

Aprovado em: 14/12/2017 